\title{
Fashion Conscious Consumers, Fast Fashion and the Impact of Social Media on Purchase Intention
}

\author{
Elram Michaela PhD \\ Steiner Lavie orna PhD \\ The college of Academic Studies or Yedua,Israel
}

Doi:10.5901/ajis.2015.v4n3s1p173

\begin{abstract}
The fashion conscious segment is an influential force within the fashion industry, which has been facilitated by the growth of the new media. However, very little research has looked at the behaviour of fashion consciousness consumers, and the impact of the social media with regard to the adoption of fashion trends and purchase intention. The study investigates the correlation between positive negative conversation in social media channels, fashion conscious consumers and increase of decrease of purchase intention. Data was gathered from a self-administered questionnaire online which was sent to women and men ages 21-65, using Google Drive. A questionnaire of 276 respondents has been encoded and the scales have been adjusted. Validated tests were performed using Step Wise linear Regression. The hypotheses that fashion conscious consumers are more influenced by social media buyers' reviews and discouraged by a negative opinion was confirmed. The study, contributes to a further theoretical understanding of the fashion conscious segment, impact of social media social media, and shopping behavior. The fast fashion segment which adopted late the social media will have to adapt to the increase impact of social media amongst different types of segments
\end{abstract}

Keywords: Consumers, Fashion, Fashion Consciousness, Social media.

\section{Introduction}

Due to increasing demand for fashion, luxury lifestyle mainly among the urban population and global growth in gross domestic product the fast fashion industry is growing $9.7 \%$ per year over the last five years, while their traditional-apparel counterparts have grown just 6.8\% per year over the same period. (Euromointor statics 2009 -2004, 2009)

The growth of the fashion industry is attributed to the Fast Fashion business model that offers new fashionable clothes every few weeks at affordable prices. Thus from an operations standpoint, fast fashion requires a quick response to new trends and frequent assortment changes (Caro \& Martinez de Albeniz, 2014)

There is an ongoing research on fast fashion dealing with consumer (Sull, 2008) behaviour (Sull \& Turconi, 2008)but few researchers move to analyses consumers' practices and habits towards fast fashion products considering the impact of the social media.

Focusing on the specific segment -fashion conscious consumers, the present study intends to fill this gap in literature, analyzing the impact of the social media on the consumption two dimensions:

a) The increase or decrease number of visiting fast fashion retailers and b) the increase or decrease of actual purchasing fashion garments as a result of social media influence.

\section{Theoretical Background}

\subsection{Fashion conscious Consumers}

Buying Behavior is the decision processes and acts of people involved in buying and using products of consumption choices and behaviours from a social and cultural point of view, as opposed to an economic or psychological one.

This academic study of consumption choices is based on economic and cultural points of view that evolve in the last 3 decades (Arnold \& Thompson, 2005). In the last 5 years due to changes in consumer level of knowledge and awareness, a new approach has focused on a new type of consumer: Strategic consumer (Cachon \& Swinney, 2009)). Strategic consumer buyer behaviour theory assumes that the constantly varying demands of consumers like waiting for 
price reduction and the changes in lifestyle have fuelled the process of renovation and more affordable prices in the fashion industry (Cachon \& Swinney, 2011)

Fashion conscious consumers can be also defined as strategic consumers as they are early fashion adopters. Having more interest in fashion, they search for more fashion-related information, shop more often, and try more new fashion items than others (Bertrandias \& Goldsmith, 2006.) (Iver \& Eastman, 2010)

It should be understood that fashion involvement is an influential driver in the consumer's fashion adoption process. Part of the fashion involvement mean seeking information about new trends new brands or price reduction

How much a consumer will be involved in the fashion will depend on his/her intention to buy that fashion. Involvement has the strongest influence on the consumer's buying behaviour

Thus the high information seeking, the quick adoption process of new trends (Cholachatpinyo, Padgett, \& Crocker, 2002) and the average amount spent (Wan et al 2001) on clothing of this segment separate fashion conscious consumers from other fashion segments (Cholachatpinyo, Padgett, \& Crocker, 2002).

According to lyer and Eastman ((Iver \& Eastman, 2010) these consumers "want to keep their wardrobe up to date with the latest style and gain pleasure from shopping'

As Increasing amount of information about new clothes is now available on social media and fashion knowledge and awareness of new fashion trends influences the adoption of new fashion items, fashion conscious consumers are more likely to be exposed to this information, and, thus, motivated to visit fast fashion retailers more frequently.

\subsection{Social media}

Social Media could be defined as "a new form of media that contain online sources that were generated, explored, utilized and spread by online users with intent to educate others about products, brands, services, events, and other topics of interest". (Rehmood \& Khan, 2011))Nowadays, internet communities, blogs, forums and social networks have become a part of life for most people, so that the social media have become alternative communication tools, supporting existing relationships and activities in a joyful way that can enrich the users' experience. Moreover, the increased use of the social media provides a platform for nurturing brands and affecting consumers' purchase decisions.

In one of the earliest research on fashion blogs (Rickman \& Cosenza, 2007) it was found that fashion couscous consumers pick up fashion ideas today from media and movies, social sharing and friends, street styles and many other places. They often talk about these ideas online and before you know it, the ideas can grow into trends.

This is why Social media is now viewed in the fast fashion industry as an opportunity to improve customer relationships and to ultimately capture a larger audience (Mohr, 2013), for example Zara has currently in 6.2 million followers on Instagram.

The importance of nowadays social comparison is becoming valid when measuring consumer conversation and interactions on Facebook Instagram and other social media channels.

Since consumers enjoy the interaction and communication with each other and like to receive advice, either positive or negative, about different products or services, virtual communities have an impact on the consumers' purchasing decision (Heinonen, 2011).

\subsection{Consumer behaviour and social media}

Social Media was at the beginning use to maintain relationships with relatives or colleagues/friends, but as the social media evolves we can see online a noticeable influence on the behaviour and consumer buying intent and implicitly on the purchase decision.

Today social media allows for the dissemination of a great deal of information about a company or product. This information isn't limited to what a company alone puts out there, because many sites within a social media network are devoted to consumer-collected information. The increased availability has changed the common consumer into a researcher. Before making a purchase, the consumer can log on to a social media network and see what other people think about products and how the company handles customer service. The more information available as outcome of conversation photos, the more likely the consumer will make the buying choice that fits his or her needs

Social media today empowers customers to help each other, which is a rewarding experience for them and builds a knowledge base for the brand. Generally, today customers as a whole know more about the products than the brand does

According to (Mir, 2012 ) thousands of internet newsgroups and online chat rooms have emerged, which are 
influencing the buying decisions of consumers. These are useful, as when a large number of online users provide the same opinion about a brand, the credibility of the brand is increases. Jonas (Jonas, 2010) also agrees with this phenomenon.

Both the social media and social networks contribute to every stage of the consumer decision-making model

Today with the social media a person who is "fashion conscious" will be aware more quickly on fashion trends and styles latest looks

As a result of these conversations and knowledge this segment often care more about some things than a brand realizes and less about what the brand thinks is important. This can affect product decisions (Kozinets, Andrea, Sarah, \& Valck, 2010).

\section{Research Hypotheses}

This study established a model in which being fashion conscious consumers, a personality trait towards adopting new fashion goods, have a direct impact on purchase intentions. In addition, this study looks at the moderating effects of the social media on this segment.

Figure 1 shows the hypothesized relationship among these variables in the model.

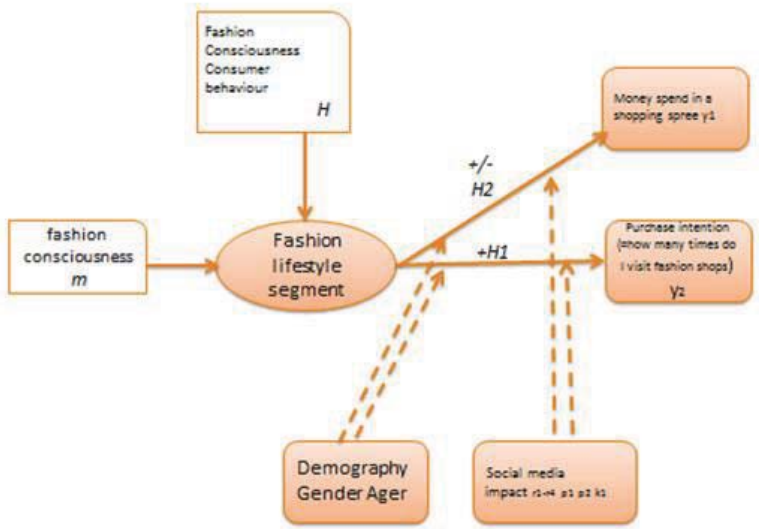

Hypothesis 1.1: As compared to late adopters, fashion conscious consumers are more likely to purchase more items of clothing products on a shopping spree to fast fashion retailers.

Hypothesis 1.2: As compared to late adopters, fashion conscious consumers are more likely to use the social media as a channel that is strengthening fashion awareness, thus, visiting fast fashion retailers more frequently.

Hypothesis 2.1: As compared to late adopters, fashion conscious consumers are more likely to buy more clothing products on a shopping spree.

Hypothesis 2.2: As compared to late adopters, fashion conscious consumers that are using the social media as a channel that is strengthening fashion awareness are spending of fashion consciousness (more or less) on a shopping spree.

\section{Methodology}

For the empirical portion of the study, two revised scales were adapted to suit the objectives of this study. Gould \& Stern, (1989) developed the first scale, used to measure fashion consciousness. Bakewell, Mitchell, \& Rothwell,( 2006)used an adapted version to measure male fashion consciousness in the United Kingdom (UK) market. For this study, items from both scales were used to reflect the dimensions of fashion consciousness (six items) and fashion conscious behaviour (six items).

Responses to scaled items were measured by using a five -point Likert scale $(1=$ strongly disagree to $5=$ strongly agree). In addition, the questionnaire included a section, designed demographic information., 
The questionnaire was translated into Hebrew and back-translated into English in order to provide coherence and an equivalence of meaning.

The data used in the research was collected by online survey through google doc

For the sampling frame, a total of 276 questionnaires were received.

\begin{tabular}{|ll|c|c|c|c|}
\hline \multicolumn{5}{|c|}{ Gender } \\
\hline \multirow{3}{*}{ Valid } & Frequency & Percent & Valid Percent & Cumulative Percent \\
& 0 = "Female" & 155 & 56.2 & 57.6 & 57.6 \\
& 1 = "Male" & 114 & 41.3 & 42.4 & 100.0 \\
Missing & Total & 269 & 97.5 & 100.0 & \\
Total & System & 7 & 2.5 & & \\
\hline
\end{tabular}

Dependent Variable: How many times do you visit fashion shops in a month (TVFS)?

\begin{tabular}{|c|c|c|c|c|}
\hline Table -.-- & Factors & $\begin{array}{c}\text { Beta } \\
\text { coefficient }\end{array}$ & $\begin{array}{c}t- \\
\text { value }\end{array}$ & $\begin{array}{l}\text { Sig. } \\
\text { level }\end{array}$ \\
\hline \multirow{4}{*}{$\begin{array}{l}\text { A linear Regression to examine the } \\
\text { predictability of fashion orientation on the } \\
\text { purchase intention of TVFS }\end{array}$} & Fashion Awareness (M) & .705 & 4.441 & .000 \\
\hline & $\begin{array}{l}\text { Do buyer's reviews on lines rating on social } \\
\text { media affect your purchase intention for a } \\
\text { particular brand? }\end{array}$ & .277 & 3.565 & .000 \\
\hline & $\begin{array}{l}\text { Consumer's behavior of consumer fashion } \\
\text { Awareness }(\mathrm{H})\end{array}$ & .510 & 2.751 & .006 \\
\hline & \multicolumn{4}{|c|}{ Notes: Significant at: $p<0.05 ; F(5,235)=2,221.5 ;$ Adjusted $R^{2}=0.93$} \\
\hline
\end{tabular}

Hypothesis 1.1: There is a correlation between fashion conscious consumers and the frequency visits to fashion stores, which is confirmed.

Hypothesis 1.2: There is a correlation between the impact of social networks on fashion conscious consumers and the frequency visits to fashion stores - confirmed.

That means that fashion conscious consumers are more influenced by a social media rating and discouraged by a negative opinion.

Dependent Variable: How much money do you spend per shopping trip (in NIS)?

\begin{tabular}{|c|c|c|c|c|}
\hline Table ---- & Factors & $\begin{array}{c}\text { Beta } \\
\text { coefficient }\end{array}$ & $\begin{array}{c}t- \\
\text { value }\end{array}$ & $\begin{array}{l}\text { Sig. } \\
\text { level }\end{array}$ \\
\hline \multirow{5}{*}{$\begin{array}{l}\text { A linear Regression to examine the } \\
\text { predictability of fashion orientation on the } \\
\text { purchase intention of TVFS by Experience }\end{array}$} & Age & .036 & 5.788 & .000 \\
\hline & Do buyer's reviews on lines rating on social & & & \\
\hline & $\begin{array}{l}\text { media affect your purchase intention for a } \\
\text { particular brand? }\end{array}$ & .206 & 3.263 & .001 \\
\hline & $\begin{array}{l}\text { Consumer's behavior of consumer fashion } \\
\text { Awareness }(\mathrm{H})\end{array}$ & .454 & 6.310 & .000 \\
\hline & Notes: Significant at: $p<0.05 ; F(5,237)=86$ & djusted $R^{2}=$ & & \\
\hline
\end{tabular}

Hypothesis 2.1: There is a correlation between fashion conscious consumers and spending (more or less) on a shopping spree. - This hypothesis was confirmed

Hypothesis 2.2: There is correlation between the impact of the social media and the spending of the fashion conscious (more or less) on a shopping spree. - this hypothesis was confirmed

What is the role of the social media in your decisions to buy apparels

\begin{tabular}{|ll|c|c|c|c|}
\hline & Frequency & Percent & $\begin{array}{c}\text { Valid } \\
\text { Percent }\end{array}$ & $\begin{array}{c}\text { Cumulative } \\
\text { Percent }\end{array}$ \\
\hline \multirow{2}{*}{ Valid } & $\begin{array}{l}\text { 1 = "It has NO ROLE to play in my apparel } \\
\text { purchases" }\end{array}$ & 68 & 24.6 & 26.0 & 26.0 \\
& $\begin{array}{l}\text { 2 = "Helps me in COMPARING PRODUCTS" } \\
\text { 3 = "It helps me in my PRELIMINARY SEARCH } \\
\text { about fashion trends" }\end{array}$ & 56 & 20.3 & 21.4 & 47.3 \\
&
\end{tabular}




\begin{tabular}{|ll|c|c|c|c|} 
& $4=$ "It helps me in SPEEDING UP THE BUYING & 46 & 16.7 & 17.6 & \\
& PROCESS. So I can avoid queues at the store" & & & & \\
& $5=$ "It helps me in ALL ASPECTS of the & 40 & 14.5 & 15.3 & 100.0 \\
& purchasing process" & 262 & 94.9 & 100.0 & \\
& Total & 14 & 5.1 & & \\
Missing & System & 276 & 100.0 & & \\
Total & &
\end{tabular}

\section{Discussion}

Over the last decade the market has witnessed dramatic changes in the buying behaviors of consumers owing to the persistent introduction of new technologies followed by progress in the social media especially. Due to these changes in the market there has been constant need for changes in our approach to consumer behaviour theory

The fashion industry was a latecomer to the social media scene, and arguably only started to make the most of the medium around 2009-10

The findings of this study suggest a strong correlation between fashion consciousness and fashion conscious segment purchase intention and a positive impact of the social media toward shopping.

What social media and the web and the era of mobile devices have given brands is the ability to speak to consumers who are hand raisers

Several managerial implications might be derived from this study.

The role of the social media in the process of purchase, when it involves fashion consensus consumers is not only an informational tool.

Consumers are believing today that social media helps them to speed up the buying process

So when a company builds social audiences that are direct, the value of this important segment- fashion conscious- can now be calculated in numerable ways.

The research shows that mangers can reduce today dependency on paid media and ultimately increase the speed with which new ideas and new products can go into the market that goes into the market

Consumers believe in seeking value for money, as they shop often and spend more or less, the research indicate the impact of the social media as an important attribute of value perception.

Thus, fast fashion apparel brands should utilize the social media to influence the decision of its consumers in buying their product, making their product known or using social media as a catalyst to positively influence different segments.

For managers of today every opportunity they have to syndicate content and increase visibility is valuable. Social media makes an easier accessibility for new customers, and makes companies more familiar and recognizable for existing customers.

Despite its limitations, this study contributes to existing literature by highlighting the powerful role that the social media can play in today's marketplace.

Social media is a place where brands can act like people do, and this is important because people like doing business with other people; not with companies.

However, there are several issues that need to be borne in mind, when reading the results of this study. Firstly, as this was a one country study, further research such as this is needed to test whether these findings can be generalized to other countries. Secondly, the study focused on the social media, the types of social media need to be explored to see if findings are transferable in a different context.

\section{References}

Arnold, E., \& Thompson, G. (2005). consumer culture theory(cct) twenty years of research. jornal of consumer research, Vol 31 No 4, 868-882.

Bakewell, Mitchell, V.-W., \& Rothwell, M. (2006). UK Generation Y male fashion consciousness. Journal of Fashion Marketing and Management: An International Journal, Vol. 10 Iss: 2, 169 - 180.

Bertrandias, L., \& Goldsmith, R. (2006). some psychologigal motivation for fashion leaders opinion leadership and fashion opinion seeking . journal of fast fashion marketing \&managment Vol. 10 no 1, 25-40.

Bertrandias, L., \& Goldsmith, R. E. (2006). Some pssychological motivations for fashion opinion leadership and fashion opinion seeking . journal of fashion marketing and managment Vol 10. No 1,22-40.

Cachon, G., \& Swinney, R. (2009). Purchasin, pricing and quick response in the present of strategic consumer. Managment sicence 55 
(3), 497-511.

Cachon, G., \& Swinney, R. (2011). The value of fast fashion: quick response, enhanced design and strategic consumer behaviour . Managment sicence vol 57 No 4, 778-795.

Caro, f., \& Martinez de Albeniz, V. (2014). fast fashion business model overview research and opportunites. new york: springer.

Cholachatpinyo, A., Padgett, I., \& Crocker, M. (2002). Aconceptual model of the fashion process- part 2 : an imperocal investigation of the micro- subject level. journal of fashion marketing\&managment Vol 16 No 6, 24-34.

Euromointor statics 2009 -2004 . (2009). fast fashion industry.

Gould, S. J., \& Stern, B. (1989). Gender schema and fashion consciousness. Psychology \& Marketing Vol 6 issue 2, 129-145.

Heinonen, K. (2011). consumer activity in social media: Manegerial approces to consumerswsocial media behaviour. Journal of consumer Behaviour Vol 10, 356-364.

Iver, r., \& Eastman, J. (2010). The fashion conscious mall shoper; An expolaratory study. The marketing managment journal vol 20 issue $2,42-53$.

Jonas, J. (2010). Source Credability of company produced and user generated content on the internet An expolatory study on the filipino youth. Philppine Managment Review 17, 121-132.

Kozinets, R., Andrea, W., Sarah, J. W., \& Valck, K. D. (2010). Networked narratives: Understanding word-of-mouth marketing in online communities. Journal of Marketing.

Mir, I. (2012 ). Verification of social media iimpact theory claims in social media context. Journal of internet banking and Commerce vol. 17 no 1.

Mohr, I. (2013). The impact of social media on the fashion idustry. Journal of applied business and economics vol 152.

Rehmood, R., \& Khan, M. I. (2011). The impact of e-Mediaon customer pruchase intention. Internation journal of Advanced computer science and application Vol2 no 1.

Rickman, T. A., \& Cosenza, R. M. (2007). "The changing digital dynamics of multichannel marketing: The feasibility of the weblog: text mining approach for fast fashion trending . Journal of Fashion Marketing and Management: An International Journal, Vol. 11 Iss: $4,, 604-621$.

Sull, D., \& Turconi, S. (2008). fast fashion lessons. Business strategi review vol 19 No 2, 83-91. 